\title{
The Life Satisfaction of Academic and Non-Academic Staff in a Malaysian Higher Education Institution
}

\author{
Kamaruzaman Jusoff (Corresponding author) \\ Yale's School of Forestry and Environmental Studies \\ Yale University, New Haven CT 06511-2104, USA. \\ Tel: 203-432-1384Ｅ-mail: jusoff.kamaruzaman@yale.edu \\ Zaliha Hj. Hussein \\ Faculty of Administrative Science and Policy Studies \\ MARA University of Technology, Peti Surat 187, 08400 Merbok, Kedah, Malaysia. \\ Tel : 60-19-411-2424Ｅ-mail : drzaliha@kedah.uitm.edu.my \\ SoonYew, Ju \\ Faculty of Administrative Science and Policy Studies \\ MARA University of Technology, Sura Hujung, 23000 Dungun, Terengganu, Malaysia. \\ Tel: 60-19-982-9784 E-mail: syju337@tganu.uitm.edu.my; jusoonyew@yahoo.com \\ Mohd Salleh Hj. Din \\ Entrepreneurship Development Institute \\ University Utara Malaysia, 06010 Sintok, UUM, Kedah, Malaysia. \\ Tel: 60-4-924-1801Ｅ-mail: salleh@uum.edu.my
}

\begin{abstract}
This study was conducted in Universiti Teknologi MARA (UiTM) Penang, Malaysia in April 2005. The objectives of the study were to examine the life satisfaction of the academic and non-academic staff. Findings revealed that some demographic variables had significant difference in life satisfaction. This study could provide meaningful information to the top management to design intervention programs to improve life satisfaction among the UiTM staff. However, since the above findings were from a case study of life satisfaction of UiTM Penang staff hence one needs to exercise caution in generalizing to the other institutions of higher education settings.
\end{abstract}

Keywords: Life satisfaction, Higher education institution, Academia

\section{Introduction}

Life satisfaction is rarely a widely researched topic. Similarly, very few research studies have been carried out in the area of life satisfaction, particularly in UiTM Penang. Therefore, this study was undertaken to examine the level of life satisfaction among the academic and non-academic staff in UiTM Penang. By attempting to address this specific problem at the institutions of higher education, this study could positively contribute towards the overall improvement of the university. Research on the staff of the institutions of higher education is becoming more and more important because researchers have examined the link between life satisfaction and job satisfaction (Kong, Ju, Maziah and Hj. Din, 2006) and the relationship among job satisfaction, life satisfaction and turnover intention.

Spector (1997) stated that life satisfaction refers to a person's feelings about life in general. Diener, Emmons, Larsen and Griffin (1985) define life satisfaction as a global evaluation by the person of his or her life and it is a cognitive and judgmental process. Thus, within this process, individuals ascertain their level of satisfaction by comparing their 
circumstances to their expectations. Life satisfaction has been researched in many contexts other than its relationship to job satisfaction and other work-related attitudes and behavior. For example, researchers have studied topics such as satisfaction with life and psychometrics properties in an adolescent sample (Neto, 1993) and student life satisfaction (Gilman \& Huebner, 2003; Sam, 2001), among others. The main thrust of the present study, however, is work-related consequences which correlate with life satisfaction.

A people's satisfaction with life could be influenced by many factors. Some researchers focus on a global assessment (Judge \& Watanabe, 1993), while other researchers concentrate on the various facets of life satisfaction. For example, Tang, Luna-Arocas and Whiteside (2003) tried to examine the relationship among money, income and life satisfaction. The variables used in their research included money ethic scale (budget, evil, equity, success, and motivator), self-reported income, demographic variables and life satisfaction. Other aspects of life could also influence life satisfaction, for instance, family life, social life and job life. In relation to this, Sekiguchi's and Kato's (2003) research divided life into three categories (family life, working life and social life) to investigate how these three were associated with the individuals' whole life satisfaction levels. Their research finding indicates that the general life satisfaction of Japanese women was high because of their good relationship with family but they were worried about health and the effects of aging for themselves and their families.

However, gender effect on life satisfaction varies from one research to another. Zhang's and Leung's (2002) prior research found that gender was not associated with general life satisfaction but was negatively associated with life domain satisfaction. This indicated that the male respondents were more satisfied with their lives than their female counterparts.

\section{Methodology}

This study evaluated the life satisfaction and selected demographic variables (category, age, gender, and years of service) among the UiTM Penang academic and non-academic staff from March-April 2005. During this period, the total population consisted of 157 academic staff and 177 non-academic staff (Department of Administration, UiTM Penang, 2005). However, staff who are currently furthering their studies and have taken non-paid leave were excluded from this study. Until the end of April 2005, 199 respondents (77 academic and 122 non-academic staff) had returned their questionnaires and found useable. Hence, analysis was based on 199 questionnaires which represented a response rate of 59.60 per cent.

\subsection{Instrumentation}

The research instruments consisted of two parts. The dependent variable was the life satisfaction, and the independent variables were demographic variables. The demographic variables included category of staff, age, gender and years of service of staff. Category of staff using the nominal scale which had two options: academic staff and non academic staff. Age data in the ordinal scale comprised the following four categories: (i) 25 years old and below, (ii) 26-35 years old (iii) 36-45 years old and (iv) 46 years old and above. Gender data using the nominal scale consisted of two options: male and female. There were three categories for the years of service variable: (i) less than 10 years, (ii) 11-20 years and (iii) more than 20 years. The questionnaire was bilingual, both in Bahasa Malaysia and English.

People's life satisfaction could be measured on various aspects, for instance, from the family satisfaction, friends' satisfaction, community satisfaction, health aspects, amongst others. For instance, Burke (1999) studied on the work and life satisfactions and psychological well being of female MBA graduates of a university in Canada in late 1996. In his study, the respondents' life satisfaction was according to three constructs, namely "family satisfaction", "friends' satisfaction", and "community satisfaction". This questionnaire contained 14 items which were adapted from Kofodimos (1995). However, the reliability of the items was not reported.

On the other hand, Diener et al., (1985) developed the Satisfaction with Life Scale (SWLS) to fulfill the need for a multi-item scale to measure life satisfaction as a cognitive-judgmental process. As discussed by Diener et al., (1985), life satisfaction stems from a judgment process by an individual and therefore they defined the life satisfaction as a global assessment by an individual about his or her life. A series of validation studies conducted by Diener et al., (1985), demonstrated that the scale was a single factor, multi-item assessment of global life satisfaction that showed good internal consistency and reliability. The SWLS has demonstrated internal consistency and reliability with a coefficient of .87 and a two-month test-retest coefficient alpha of .85 (Diener et al., 1985). This scale has been used extensively (Neto, 1993; Landry, 2000). For instance, Neto's (1993) research used this instrument to measure the psychometrics properties in an adolescent sample, where the internal consistency coefficient was 0.78 . Landry's (2000) study showed that the coefficient alpha for SWLS was .87. Due to all the above reasons, this questionnaire was used in this study. To measure life satisfaction of the staff, five items from the SWLS were used. A 7 point Likert scale was used to record the responses. Possible responses ranged from 1 (strongly disagree) to 7 (strongly agree). The range of possible scores is from minimal satisfaction with life (5) to very high satisfaction with life (35). 
The collected data were analyzed using Statistical Package for Social Science (SPSS) Version 12 with the following tests: (i) the descriptive data of staff ; (ii) the life satisfaction is measured using the mean values differences, if there is a significant, further analysis on mean values differences will be conducted to substantiate the findings.

\subsection{Reliability Analysis}

The Cronbach Alpha reliability test was carried out to ensure the reliability of the instrument. The coefficient reliability for life satisfaction was at .8196 . According to Nunnaly (1978) a reliability coefficient of .70 and above is high.

\section{Results}

\subsection{Demographic characteristics}

In this study, four demographic variables (category, age, gender and years of service) of UiTM Penang staff are used as independent variables to investigate their relationships with life satisfaction. Table 1 - Table 4 illustrates the means, frequencies and percentages for UiTM Penang staff, as summarized below:

(i) Table 1 displays the distribution of the Penang staff category: academic was $38.7 \%(n=77)$ and non-academic staff was $61.3 \%(n=122)$.

(ii) Table 2 shows the distribution of age group among the Penang staff: 25 and below was $15.6 \%(\mathrm{n}=31), 26$ - 35 years old was $36.7 \%(\mathrm{n}=73), 36-45$ years old was $32.2 \%(\mathrm{n}=64)$ and 46 and above was $15.6 \%(\mathrm{n}=31)$.

(iii) Table 3 displays the gender composition of the Penang staff in the following group: male was $56.3 \%(\mathrm{n}=112)$ and female was $43.7 \%(\mathrm{n}=87)$.

(iv) Table 4 indicates the years of service of Penang staff: less than 10 years was $79.4 \%(\mathrm{n}=158), 11-20$ years was $12.6 \%(\mathrm{n}=25)$ and more than 20 years was $8.0 \%(\mathrm{n}=16)$.

\subsection{Research questions and hypotheses testing}

In this study, the significant level of null hypotheses testing value was set at 0.05 . Thus, any null hypotheses testing value that is above $0.05(\mathrm{p}>0.05)$ cannot be rejected.

\subsubsection{Research question 1: What is the level of life satisfaction of the UiTM Penang staff?}

The finding suggested that the mean value for life satisfaction of the UiTM Penang staff was 4.7417 (Table 5). Since the mean values was closer to the maximum point (likert scale 1-7), the finding suggested that the staff at UiTM Penang were moderately satisfied with their life.

3.2.2 Research question 2: Were the staff's demographic variables (category, age, gender, and years of service) related to the life satisfaction level of UiTM Penang staff?

\section{Null Hypothesis 2 (Ho2):}

There were no differences between the life satisfaction level of UiTM Penang staff and the selected demographic variables (category, age, gender and years of service).

\section{Null Hypothesis 2a (Ho2a):}

Ho2a: There was no difference in the life satisfaction level between the category of academic and non-academic staff of UiTM Penang.

To test the null Hypothesis 2a (Ho2a), a independent samples t-test was conducted to evaluate the difference between the categories on the life satisfaction of UiTM Penang staff as shown in Table 6.

Significant differences were not found on the life satisfaction between the category of academic and non-academic Penang staff. The level of significant level is at $\mathrm{p}=0.159$. Thus the null hypothesis could not be rejected.

Null Hypothesis $2 \mathrm{~b}$ (Ho2b):

Ho2b: There was no difference in the life satisfaction level of UiTM Penang staff based on their age.

To test the above null hypothesis $2 \mathrm{~b}$ (Ho2b), the one-way ANOVA was conducted to evaluate the differences between age of the Penang staff and the life satisfaction as shown in tables 7 and 8.

Table 8 presented the result of the one-way ANOVA analysis between the life satisfaction and age of the Penang staff. The level of significant level is at $p=0.001$. Thus the null hypothesis was rejected. Finding indicated that group of staff in the age of 46 and above indicates higher mean values (mean=5.3806) as compared to others (Table 7 and Figure 1).

Null Hypothesis 2c (Ho2c):

Ho2c: There was no difference in the life satisfaction level between male and female staff of UiTM Penang.

To test the null Hypothesis 2c (Ho2c), a independent samples t-test was conducted to evaluate the difference between gender for the life satisfaction level of UiTM Penang staff as shown in Table 9. 
Significant differences were not found on the life satisfaction between the male and female Penang staff. The level of significant level is at $\mathrm{p}=0.223$. Thus the null hypothesis could not be rejected.

Null Hypothesis $2 \mathrm{~d}(\mathrm{Ho} 2 \mathrm{~d})$ :

Ho2d: There is no difference between the life satisfaction level according to the years of service of the UiTM Penang staff.

To test the null hypothesis $2 \mathrm{~d}(\mathrm{Ho} 2 \mathrm{~d})$, the one-way ANOVA was conducted to evaluate the differences between years of service of the Penang staff and life satisfaction level as shown in tables 10 and 11.

Table 11 presents the result of the one-way ANOVA analysis between life satisfaction and years of service of UiTM Penang staff. The level of significant level is at $\mathrm{p}=0.031$. Thus the null hypothesis was rejected. The finding suggested that the group of staff who served more than 20 years enjoyed higher mean values (mean $=5.3125$ ) as compared to others (Table 10 and Figure 2).

\section{Conclusion}

This case study was carried out to investigate the overall life satisfaction level of UiTM Penang staff. In relation to that, there were two research questions. A few important findings pertaining to the research objectives are also summarized and discussed:

Research Question 1: What is the level of life satisfaction of the UiTM Penang staff? Findings suggested that the UiTM Penang staff were moderately satisfied with their life.

Research Question 2: Were the staff's demographic variables (category, age, gender, and years of service) related to the life satisfaction level of UiTM Penang staff? Finding showed that for UiTM Penang staff, there were significant differences between demographic variables (age and years of service) and life satisfaction. However there was no significant difference in life satisfaction according to the category of staff and gender.

The implications of these findings to the university's top management would be to improve the level of life satisfaction among its staff, as numerous researches have suggested that there are relationships between life satisfaction, job satisfaction and intention to leave the organization (Landry, 2000; Ghiselli, La Lopa \& Bai, 2001). Therefore, future researches should expand the scope of this study to find out if there are other possible factors that influence life satisfaction, for instance the relationship between job satisfaction and life satisfaction (Kong, Ju, Maziah \& $\mathrm{Hj}$. Din, 2006) and the relationship between job satisfaction, life satisfaction and turnover intention among employees in UiTM and other institutions of higher education in Malaysia.

\section{References}

Burke, R. J. (1999). Workholism among women managers: Work and life satisfactions and psychological well-being. Equal Opportunities International, 18(7), 25-35.

Diener, E., Emmons, R. A., Larsen, R. J., \& Griffin, S. (1985). The Satisfaction with Life Scale. Journal of Personality Assessment, 49(1), 71-75.

Ghiselli, R. F., La Lopa, J. M., \& Bai, B. (2001). Job satisfaction, life satisfaction, and turnover intent: Among food-service managers. Cornell Hotel and Restaurant Administration Quarterly, 42(2), 28-37.

Gilman, R., \& Huebner, S. (2003). A review of life satisfaction research with children and adolescents. School Psychology Quarterly, 18(2), 192.

Judge, T. A., \& Watanable, S. (1993). Another look at the job satisfaction-life satisfaction relationship. Journal of Applied Psychology, 78, 939-948.

Kofodimos, J. (1995). Balancing act. San Francisco: Jossey-Bass.

Kong, L. K., Ju, S. Y., Maziah Onn., \& Hj. Din, M. S. (2006). The academic staff's job and life satisfaction: A case study on Mara University of Technology, Perlis. In proceeding of the South East Asian Association for Institutional Research (SEEAIR) 2006 conference. 5 - 7 September, Awana Porto Malai Resort, Langkawi, Malaysia.

Landry, M. B. (2000). The effects of life satisfaction and job satisfaction on reference librarians and their work. Reference \& User Services Quarterly, 40(2), 166-177.

Neto, F. (1993). The satisfaction with life scale: Psychometrics properties in an adolescent sample. Journal of Youth and Adolescence, 22(2), 125-134.

Nunnaly, J. C. (1978). Psychometric theory. New York: McGraw-Hill.

Sam, D. L. (2001). Satisfaction with life among international students: An exploratory study. Social Indicators Research, 53(3), 315. 
Sekiguchi, K. \& Kato, K. (2003). Job satisfaction and job satisfaction levels of female graduates of a Japanese University. Proceedings of the 47th Annual Meeting of the International Society for the Systems Science, at Hersonissos.

Spector, P. E. (1997). Job satisfaction: Application, assessment, causes and consequences. Thousand Oaks, CA: SAGE Publication.

Tang, T. L. P., Luna-Arocas, R., \& Whiteside, H. D. (2003). Money ethic endorsement, self-reported income, and life satisfaction: University faculty in the US and Spain. Personnel Review, 32(6), 756-773.

Zhang, L. W., \& Leung, J. P. (2002). Moderating effects of gender and age on the relationship between self-esteem and life satisfaction in mainland Chinese. International Journal of Psychology, 37(2), 83-91.

Table 1. Staff by Category

\begin{tabular}{llccrc}
\hline & Frequency & Percent & $\begin{array}{c}\text { Valid } \\
\text { Percent }\end{array}$ & $\begin{array}{c}\text { Cumulative } \\
\text { Percent }\end{array}$ \\
\hline \multirow{2}{*}{ Valid } & Academic & 77 & 38.7 & 38.7 & 38.7 \\
& Non-Academic & 122 & 61.3 & 61.3 & 100.0 \\
& Total & 199 & 100.0 & 100.0 &
\end{tabular}

Table 2. Staff by Age Groups

\begin{tabular}{llcccc}
\hline & Frequency & Percent & $\begin{array}{c}\text { Valid } \\
\text { Percent }\end{array}$ & $\begin{array}{c}\text { Cumulative } \\
\text { Percent }\end{array}$ \\
\hline Valid & 25 and below & 31 & 15.6 & 15.6 & 15.6 \\
& $26-35$ & 73 & 36.7 & 36.7 & 52.3 \\
& $36-45$ & 64 & 32.2 & 32.2 & 84.4 \\
46 and above & 31 & 15.6 & 15.6 & 100.0 \\
& Total & 199 & 100.0 & 100.0 &
\end{tabular}

Table 3. Staff by Gender

\begin{tabular}{llcccc}
\hline & & Frequency & Percent & $\begin{array}{c}\text { Valid } \\
\text { Percent }\end{array}$ & $\begin{array}{c}\text { Cumulative } \\
\text { Percent }\end{array}$ \\
\hline \multirow{2}{*}{ Valid } & Male & 112 & 56.3 & 56.3 & 56.3 \\
& Female & 87 & 43.7 & 43.7 & 100.0 \\
& Total & 199 & 100.0 & 100.0 &
\end{tabular}

Table 4. Staff by Years of Service

\begin{tabular}{llrrrr}
\hline & Frequency & Percent & $\begin{array}{c}\text { Valid } \\
\text { Percent }\end{array}$ & $\begin{array}{c}\text { Cumulative } \\
\text { Percent }\end{array}$ \\
\hline \multirow{2}{*}{ Valid } & Less than 10 years & 158 & 79.4 & 79.4 & 79.4 \\
& 11-20 years & 25 & 12.6 & 12.6 & 92.0 \\
& More than 20 years & 16 & 8.0 & 8.0 & 100.0 \\
Total & 199 & 100.0 & 100.0 &
\end{tabular}


Table 5. Mean and Standard Deviation for Life Satisfaction of UiTM Penang Staff

\begin{tabular}{lccc}
\hline & \multicolumn{3}{c}{ UiTM Penang Staff } \\
& N & Mean & SD \\
\hline Life Satisfaction & 199 & 4.7417 & 1.04457
\end{tabular}

Table 6. Mean and Standard Deviation for the Life Satisfaction that Compare Academic and Non-Academic Penang Staff

\begin{tabular}{lcccccccc}
\hline & \multicolumn{3}{c}{ Academic } & \multicolumn{7}{c}{ Non-Academic } \\
& $\mathrm{N}$ & Mean & $\mathrm{SD}$ & $\mathrm{N}$ & Mean & $\mathrm{SD}$ & $\mathrm{t}$ & $\mathrm{p}$ \\
\hline Life & & & & & & & & \\
Satisfaction & 77 & 4.6104 & 1.05725 & 122 & 4.8246 & 1.03223 & -1.412 & .159
\end{tabular}

* Indicated statistical significance.

Table 7. Descriptive Statistics for the Life Satisfaction that compares Age of the Penang Staff

Life Satisfaction

\begin{tabular}{|c|c|c|c|c|c|c|c|c|}
\hline & \multirow[t]{3}{*}{$\mathrm{N}$} & \multirow[t]{3}{*}{ Mean } & \multirow[t]{3}{*}{$\begin{array}{l}\text { Std. } \\
\text { Dev. }\end{array}$} & \multirow[t]{3}{*}{$\begin{array}{l}\text { Std. } \\
\text { Error }\end{array}$} & \multicolumn{2}{|c|}{$\begin{array}{l}95 \% \text { Confidence } \\
\text { Interval for Mean }\end{array}$} & \multirow[t]{3}{*}{ Min. } & \multirow[t]{3}{*}{ Max. } \\
\hline & & & & & Lower & Upper & & \\
\hline & & & & & Bound & Bound & & \\
\hline 25 and below & 31 & 4.4065 & 1.08010 & .19399 & 4.0103 & 4.8026 & 2.00 & 6.40 \\
\hline $26-35$ & 73 & 4.5918 & 1.05643 & .12365 & 4.3453 & 4.8383 & 1.80 & 7.00 \\
\hline $36-45$ & 64 & 4.7656 & .95123 & .11890 & 4.5280 & 5.0032 & 1.80 & 6.60 \\
\hline 46 and above & 31 & 5.3806 & .92859 & .16678 & 5.0400 & 5.7213 & 3.40 & 7.00 \\
\hline Total & 199 & 4.7417 & 1.04457 & .07405 & 4.5957 & 4.8877 & 1.80 & 7.00 \\
\hline
\end{tabular}

Table 8. One-Way ANOVA Analysis between Life Satisfaction (dependent variable) and Age (independent variable) of the Penang Staff

Life Satisfaction

\begin{tabular}{lrrrrr}
\hline & Sum of Squares & \multicolumn{1}{c}{ df } & Mean Square & F & Sig. \\
\hline Between Groups & 17.817 & 3 & 5.939 & 5.842 & .001 \\
Within Groups & 198.227 & 195 & 1.017 & & \\
Total & 216.044 & 198 & & & \\
& & & & & \\
\hline
\end{tabular}

Table 9. Mean and Standard Deviation for Life Satisfaction that Compare Male and Female Penang Staff

\begin{tabular}{lcccccccc}
\hline & \multicolumn{9}{c}{ Male } & \multicolumn{7}{c}{ Female } \\
& $\mathrm{N}$ & Mean & $\mathrm{SD}$ & $\mathrm{N}$ & Mean & $\mathrm{SD}$ & $\mathrm{t}$ & $\mathrm{p}$ \\
\hline $\begin{array}{l}\text { Life } \\
\text { Satisfaction }\end{array}$ & 112 & 4.8214 & 1.06046 & 87 & 4.6391 & 1.02064 & 1.223 & .223
\end{tabular}

* Indicated statistical significance. 
Table 10. Descriptive Statistics for Life Satisfaction that compares Years of Service of the Penang Staff Life Satisfaction

\begin{tabular}{|c|c|c|c|c|c|c|c|c|}
\hline & \multirow[t]{3}{*}{$\mathrm{N}$} & \multirow[t]{3}{*}{ Mean } & \multirow[t]{3}{*}{$\begin{array}{l}\text { Std. } \\
\text { Dev. }\end{array}$} & \multirow[t]{3}{*}{$\begin{array}{l}\text { Std. } \\
\text { Error }\end{array}$} & \multicolumn{2}{|c|}{$\begin{array}{l}\text { 95\% Confidence } \\
\text { Interval for Mean }\end{array}$} & \multirow[t]{3}{*}{ Min. } & \multirow[t]{3}{*}{ Max. } \\
\hline & & & & & Lower & Upper & & \\
\hline & & & & & Bound & Bound & & \\
\hline Less than 10 years & 158 & 4.6519 & 1.08872 & .08661 & 4.4808 & 4.8230 & 1.80 & 7.00 \\
\hline $11-20$ years & 25 & 4.9440 & .75613 & .15123 & 4.6319 & 5.2561 & 3.40 & 6.20 \\
\hline More than 20 years & 16 & 5.3125 & .76234 & .19059 & 4.9063 & 5.7187 & 3.60 & 6.40 \\
\hline Total & 199 & 4.7417 & 1.04457 & .07405 & 4.5957 & 4.8877 & 1.80 & 7.00 \\
\hline
\end{tabular}

Table 11. One-Way ANOVA Analysis between Life Satisfaction and Years of Service of the Penang Staff Life Satisfaction

\begin{tabular}{lrrrrr}
\hline & Sum of Squares & \multicolumn{1}{c}{ df } & Mean Square & F & Sig. \\
\hline Between Groups & 7.510 & 2 & 3.755 & 3.529 & .031 \\
Within Groups & 208.534 & 196 & 1.064 & & \\
Total & 216.044 & 198 & & & \\
& & & & & \\
\hline
\end{tabular}

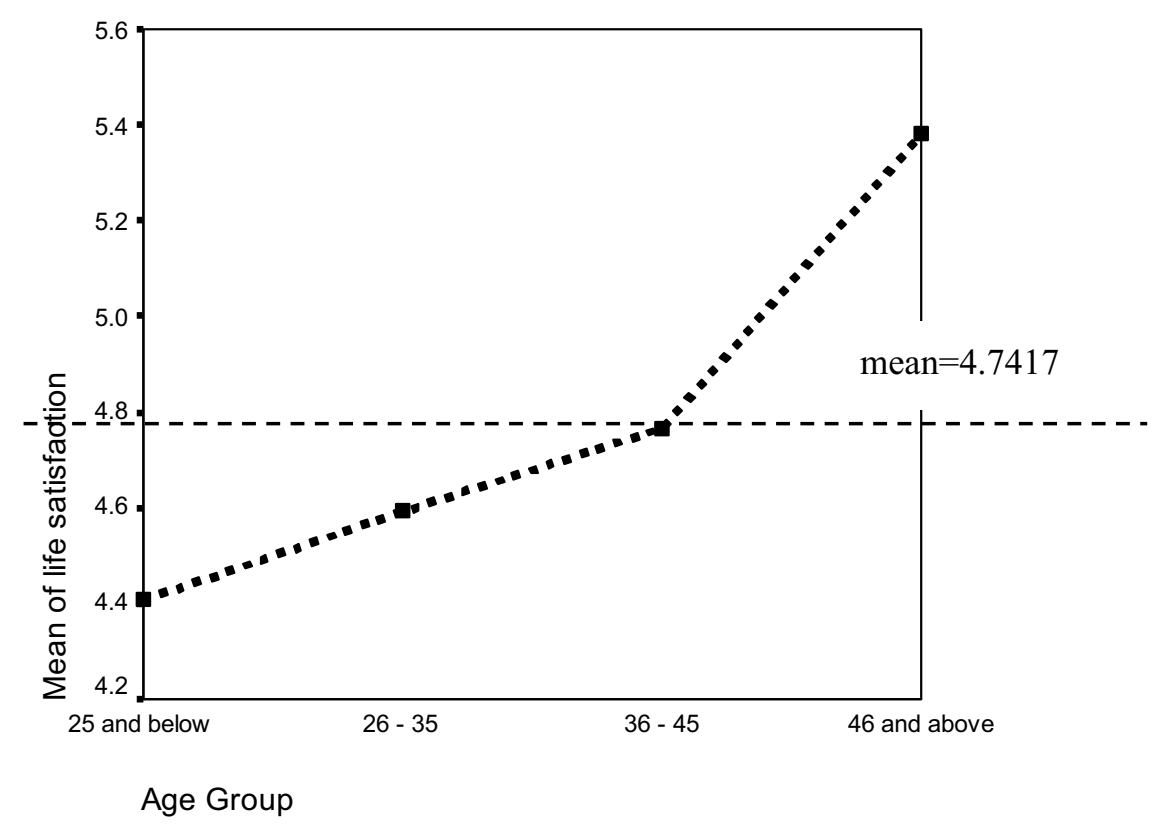

Figure 1. Mean for Life Satisfaction Level (Age Group) 


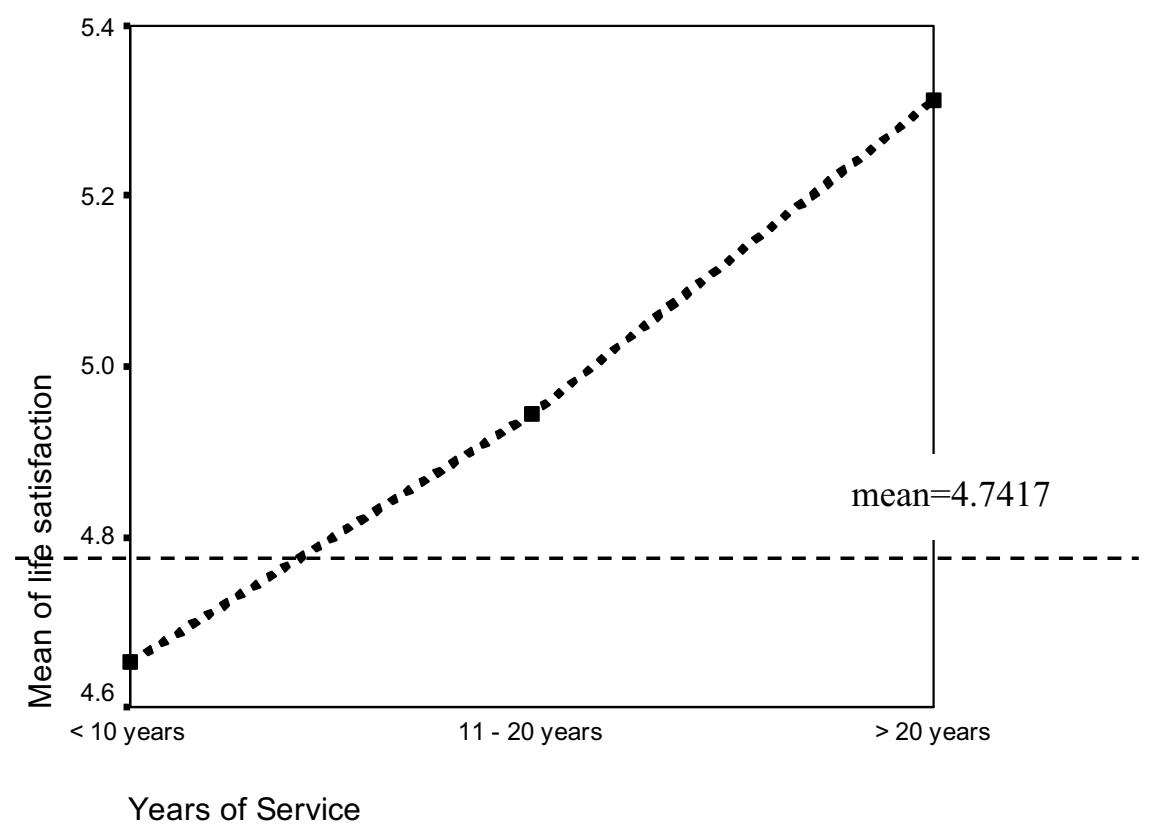

Figure 2. Mean for Life Satisfaction Level (Years of Service) 